\title{
INVESTIGATION OF OSCILLATORY DISPLACEMENT OF THE HYDRAULIC PRESSES MOVING PARTS DURING THEIR BRAKING IN THE UPPER INITIAL POSITION
}

\section{Olena Korchak}

\author{
Donbas National Academy of Civil Engineering and Architecture, \\ Kramatorsk, Ukraine
}

\begin{abstract}
Summary. The investigations revealed that, despite the usage of individual servo drive of the inlet valve of return cylinders, ram overrun upwards after its being shut down which is accompanied by intensive oscillatory phenomena is inevitable. By analyzing the experimental diagrams it is stated that the existing mechanism of ram braking in upper starting position is unacceptable from the point of view of fast and non-impact process realization, as well as the accuracy of stoppage. The mathematical model of ram damped oscillations in the upper position after the inlet valve of return cylinders shut down, which takes into account the parameters of oscillatory system consisting of ram and fluid masses in power and return cylinders, is developed. A numerical analysis of the developed mathematical model established that when using counterbalance cylinders in press design, the period of oscillations increases with decreasing the amplitude. Besides, the complete damping of the oscillations occurs earlier than in the case of counterbalance cylinders absence.

Key words: hydraulic press, ram, oscillations, pressure, control valve, overrun, braking, counterbalance cylinder.
\end{abstract}

Statement of the problem. The speed of hydraulic presses with a wide range of forces is the result of rational design of their drives and the correct selection of control devices that provide fast and non-impact acceleration and braking of moving masses [1]. During the main stages of the press machine cycle, it is necessary to reverse not only the metal moving parts, but also the elastic columns of high and low pressure fluid in the pipelines [2]. However, when the transients in the hydraulic drive during acceleration and braking coincide with the reverse of the moving masses, for example, in the upper initial position, the oscillation and hydraulic impact effects of different intensity occur [3].

Analysis of the available results of researches. The most common method of braking the moving parts of the hydraulic drive is to change the resistance of the respective hydraulic lines by using throttle control valves as a braking device [3]. They can be installed both in a pressure head, and in a drain hydroline. Regardless of the braking moving parts method, the operation of braking devices is based on two main principles $[4,5]$ - reducing the amount of energy supplied by the working fluid to the actuator (cylinder), and increasing the resistance to moving masses.

In relation to the hydraulic presses, the moving parts in the upper position are braked by closing the inlet valve of the return cylinders, which achieves a reduction in the active lifting force and the moving masses slow down their motion [6]. In this case, the braking device - a closed inlet valve - is installed in the pressure hydraulic line.

When making a mathematical model of braking the moving parts in the upper position, it is impossible to study oscillating and hydraulic impact phenomena without taking into account the elasticity of the working medium, because neglecting the elasticity in describing transients in the hydraulic drive leads to significant errors in simulation [3, 7]. 
Objectives of the research. To increase the speed of hydraulic presses, it is necessary to study the oscillation displacements of the moving parts of hydraulic presses during their braking in the upper initial position and to identify the main factors of the oscillating system that influence the intensity of damping of oscillating motion. This will make it possible to develop rational modes of fast and non-impact braking of moving parts for productive operation of the equipment in the conditions of automatic motion.

Results of the research. In Figure 1, a typical braking diagram of the moving parts in the upper position is shown. To analyze the processes taking place in the hydraulic press within this stage, the period drawn in Figure 1 should be divided into several separate intervals:

- interval I - closing of the inlet throttle control valve of return cylinders (curve 3);

- interval II - ram displacement (curve 1) after the closure of inlet valve of return cylinders (curve 3 ).

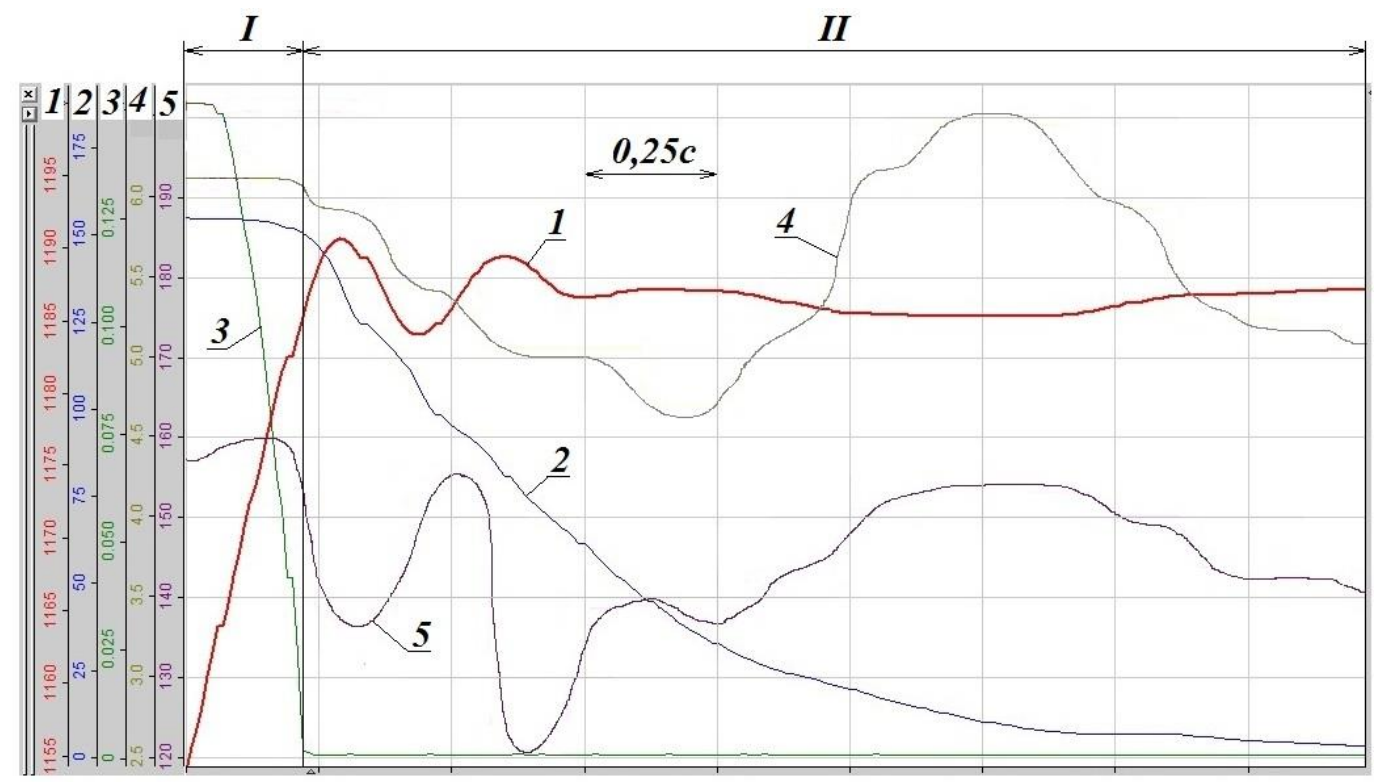

Figure 1. Diagram of ram braking in upper starting position of hydraulic forging press with active force of $30 \mathrm{MN}$ : 1 - ram displacement; 2 - ram speed; 3 - stroke of inlet valve of return cylinders; 4 - pressure in power cylinders; 5 - pressure in return cylinders

Before the closure of inlet valve of return cylinders (curve 3), the ram (curve 1) moves upwards with the constant speed (curve 2) $155 \mathrm{~mm} / \mathrm{s}$. The pressure in the return cylinders (curve 5 ) is $15.8 \mathrm{MPa}$, and in operating ones (curve 4) it is $0.6 \mathrm{MPa}$.

Interval $\mathrm{I}$, the duration of which is approximately $0.2 \mathrm{~s}$, corresponds the time of inlet valve of return cylinders closure (curve 3 ). Herewith the ram (curve 1) almost does not react on the closure of the regulation valve (curve 3 ) and continues its motion upwards with the speed $150 \mathrm{~mm} / \mathrm{s}$.

Interval II illustrates the oscillation in the period of the ram run-out (curve 1) on its return after the inlet valve of the return cylinders closing (curve 3). During the first $0.1 \mathrm{~s}$ of the interval II the ram (curve 1) intensive $6.2 \mathrm{~mm}$ run-out upwards during which the pressure in the return cylinders abruptly falls to the level of $13.6 \mathrm{MPa}$. The inlet valve (curve 3 ) is locked, there is a working fluid column and within the closed hydraulic line medium 'inlet valve - return cylinders', which extends during run-out and that brings to the decrease of pressure in the return cylinders. During the run-out the ram speed (curve 2) falls to $136 \mathrm{~mm} / \mathrm{s}$. 
Closing the inlet valve of the return cylinders (curve 3 ) causes a loss of active lifting force, which together with the forces of friction and viscous hydraulic resistance lead to the ram stop (curve 1) at the highest point of 1191 points.

Then, under the action of its own weight and the column of fluid compressed in the hydraulic line «intake valve - return cylinders», the ram (curve 1) begins its downward movement by $7.4 \mathrm{~mm}$, skipping the upper mark, which corresponds to its position at the moment of closing the intake valve of return cylinders (curve 3), and stopping at the lowest point.

The pressure of the working fluid on the return valves (curve 5) rises to $15.5 \mathrm{MPa}$ due to compression of the fluid column in the hydraulic line 'intake valve - return cylinders'. On the contrary, in the working cylinders (curve 4), the pressure falls to the level $0.53 \mathrm{MPa}$ because of their fluid column extension.

The ram stop (curve 1) in the extreme lower position occurs under the pressure that rises in the return cylinders (curve 5) and viscous hydraulic resistance combined with the friction forces. By the moment of ram stop (curve 1), its speed (curve 2) decreases to $107 \mathrm{~mm} / \mathrm{s}$.

Then the ram rises (curve 1), after that another lowering follows - there are the ram oscillations (curve 1) after the intake valve of the return cylinders closing (curve 3). Because of presence of the friction forces and the viscous hydraulic resistance, oscillations are of damping character. The ram stop (curves 1 and 2) occurs only in $2 \mathrm{~s}$ after the time of intake valve return cylinders closing (curve 3 ).

Thus, the experimental studies show that the ram upward run-out after closing the intake valve of the return cylinders, followed by intense oscillations, is inevitable. In this case, the oscillations are produced not only by the ram, but also by the fluid volumes in the working and return cylinders. Given the fact that the volume of the working cylinders on average significantlye exceeds the volume of the return ones and, therefore, has greater inertia, in the process of oscillations there is dissonance, which leads not to damping but to increase of oscillations of moving masses, as evidenced by the pattern observed in the second half of interval II (Fig. 1). Due to the significant difference in pressure levels in the working and return cylinders, the resulting oscillations have an amplitude of not more than $4.5 \mathrm{~mm}$. The described oscillatory phenomena are accompanied by hydraulic impacts of different intensity. Due to the lack of a system of counterbalance cylinders directly connected to the accumulator in the design of the press, there is no permanent support from below, which on one hand would not allow the ram to intensively move down, and on the other - would be a damping element that damps the oscillations.

In view of the above, it can be stated that the existing mechanism of ram braking is unacceptable in terms of rapid and non-impact implementation of the process, as well as the accuracy of stopping ram in the upper position. Despite the fact that the return stroke does not deform the workpiece, the accuracy of ram stopping is very important, because it reduces the duration of the machine cycle, improves the quality of press control and facilitates programming of the automated control system. If in the conditions of single strokes the ram oscillations damp during the technological pause, the minimum allowable time of which will have to be calculated taking into account the described phenomena, then in case of press operation in automatic mode reversal of movable masses (metal and fluid) in the upper position will be followed by the intensive hydraulic impacts and a abrupt fall of pressure in the working cylinders when they are filled with liquid from the tank at the beginning of the next downward stroke.

It should be noted that the data and curves shown in Figure 1 are the result of experimental studies of hydraulic presses with pump-accumulator drive, conducted in real industrial conditions using the appropriate sensors from Bosch REXROTH and BALLUFF. The experimental research techniques, scheme of sensors location and adjustment, as well as methods of theoretical and experimental determination of the basic parameters of the equipment 
are described by the author of this article in detail in [8], and for this reason are not fully presented in the main part of present research.

The analysis of the obtained experimental data was carried out using a special software package iba Analyzer. According to the linear sensors settings for monitoring the ram position and the speed of its movement (curves 1 and 2 in Figure 1), all current sensor data were passed through digital filters with noise cancellation and taken modulo. Due to digital smoothing in Figure 1 (and then in other figures) in places of physical change of the sign of the ram speed to the opposite and reaching zero values at extreme points, the corresponding speed curves have sloping sections - i.e., speed curves are shown stepwise.

In the subsequent numerical analysis of the mathematical model of atennuated oscillations of moving parts, the same principle was applied in relation to the obtained corresponding values, especially to those in the specified places where curves of speed may be more sloping at increasing values of accelerations. This was done specifically to adapt the developed mathematical model to the automatic control systems of hydraulic presses with pump-accumulator drive and individual servo drive, operating within automated complexes, as described in [8].

Oscillations of the moving parts in the upper position are of distinct damping nature, because of friction in the oscillating motion. In [9-11] it is noted that the most rational in terms of speed is braking with constant acceleration. Displacement of moving masses is described by the equation of damping oscillations with a constant frequency and gradually decreasing deviations [12]

$$
\frac{d V}{d t}\left[a+\frac{k_{b}}{\omega^{2}}\left(1-\varepsilon \cdot e^{-h \cdot t}\left(\cos (\omega t)+\frac{h}{\omega} \sin (\omega t)\right)\right)\right]-c=0,
$$

where $V$ is the speed of the moving parts displacement; $t$ is the current value of time; $a$ are moving masses of metal and working fluid in different parts of the hydraulic drive reduced to a ram; $c$ is the sum of active and resistance forces acting on moving parts; $k_{b}$ is the linear rigidity of the «inlet valve - return cylinders» line, reduced to ram; $h$ and $\omega$ are the parameters of oscillatory system; $\varepsilon$ - correction factor that takes into account the dissipative properties of the oscillatory system.

Expression (1) is a mathematical model of the damping oscillations of the moving parts when they are braked in the upper initial position (after closing the inlet valve of the return cylinders). For its analytical solution it is necessary to determine the parameters of the oscillating system. The theoretical method of their determination is inconvenient due to the difficulty of taking into account all the factors influencing the oscillatory process of metallic moving masses and the fluid mass reduced to them. Therefore, the most reliable is to determine the required parameters using experimental diagrams as follows.

In Figure 2, the diagram of ram oscillating displacement (curve 1) after inlet valve of return cylinders being shut down is presented. The corresponding parameters of the oscillating system are shown in the diagram (Fig. 2) and are calculated by the following formulas:

- oscillations frequency

$$
\omega=\frac{2 \pi}{T}
$$

where $T$ is the period of oscillations (Fig. 2);

- logarithmic decrement of damped oscillations 


$$
\delta=\ln \frac{A_{t}}{A_{t+T}}
$$

where $A_{t}, A_{t+T}$ are amplitudes of two consecutive oscillations (Fig. 2);

- coefficient characterizing the viscous resistance of the system

$$
h=\frac{\delta}{T}
$$

- corrective coefficient of oscillating motion

$$
\varepsilon=\frac{A_{t}}{A_{\max }}
$$

where $A_{\max }$ is the maximum value of the amplitude, theoretically determined by the Riccatti formula at a steady displacement of moving parts during operation [6].

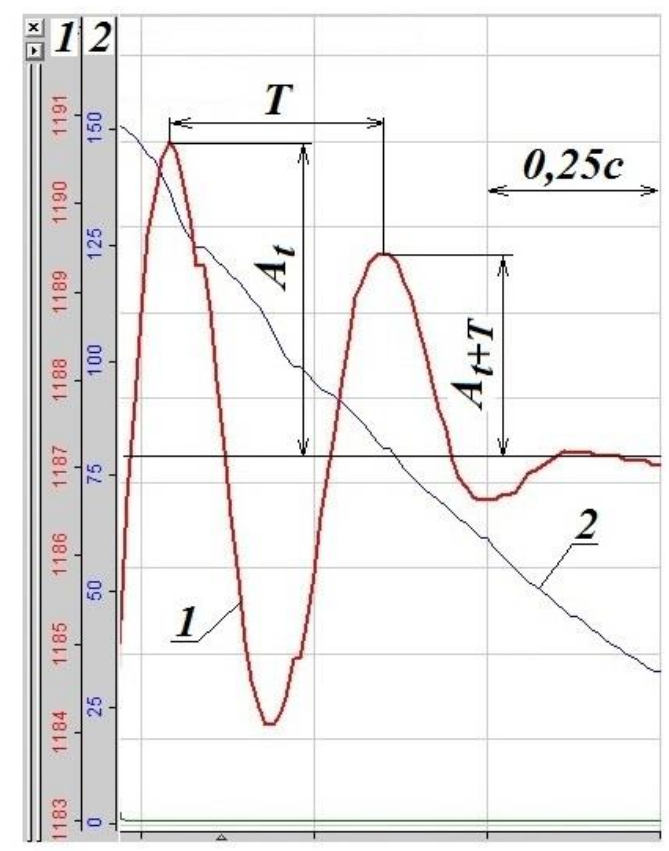

Figure 2. Diagram of ram oscillating displacement after inlet valve of return cylinders being shut down

The method of theoretical and experimental determination of other parameters used in equation (1) is described in detail in the works $[8,9]$ of the author and is not given in this article.

Equation (1) of the damping oscillations of the moving parts during their braking in the upper initial position (after closing the inlet valve of the return cylinders) was solved by the numerical Runge-Kutta method for the typical braking process shown in the diagram (Fig. 1). Figure 3 shows the curves of changes in speed $(V)$, displacement $(S)$ and acceleration $(J)$ of moving parts when oscillating in the upper position of the hydraulic press with a force of $30 \mathrm{MN}$. 


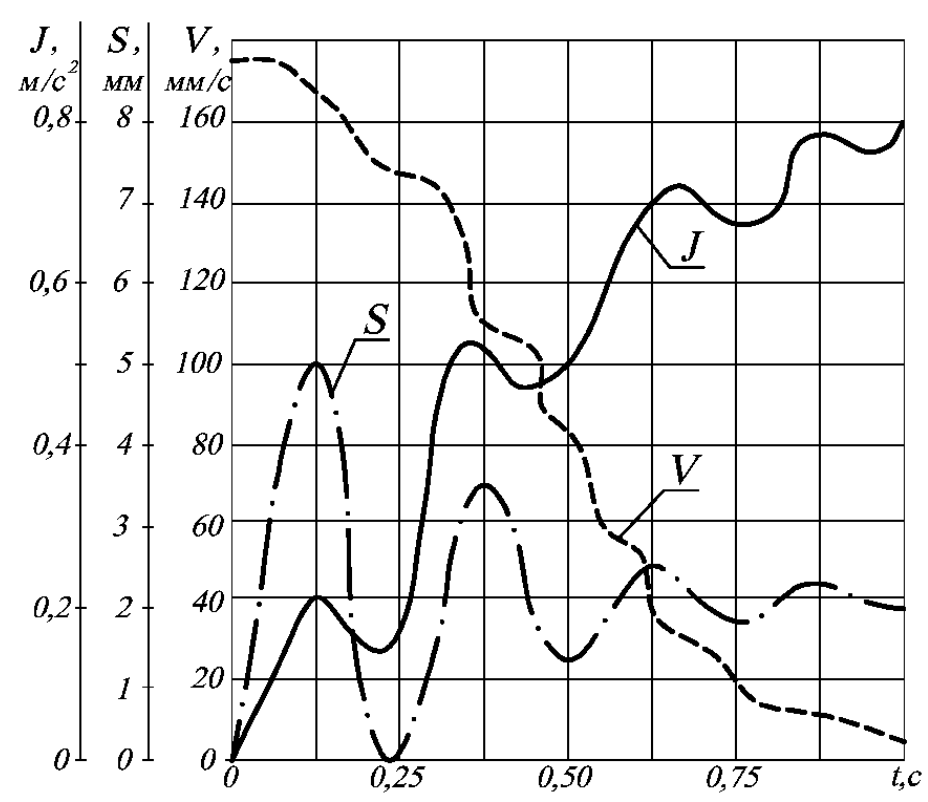

Figure 3. Curves of ram speed, displacement and acceleration while oscillating in the upper position

The graph (Fig. 3) shows that the oscillatory process is accompanied by a gradual increase in acceleration $J$ to the value $0.8 \mathrm{~m} / \mathrm{s}^{2}$. As a result, the ram speed $V$ for $1 \mathrm{~s}$ is gradually reduced from $175 \mathrm{~mm} / \mathrm{s}$ to $7 \mathrm{~mm} / \mathrm{s}$. Thus the ram does oscillating motions $S$ with the maximum amplitude $5 \mathrm{~mm}$ and by the end of the considered period practically stops $2 \mathrm{~mm}$ above necessary level.

The curves (Fig. 3) are drawn in the absence of a system of counterbalance cylinders in the design of the press. Their introduction into the press control system significantly changes the dynamic pattern of oscillations (Fig. 4).

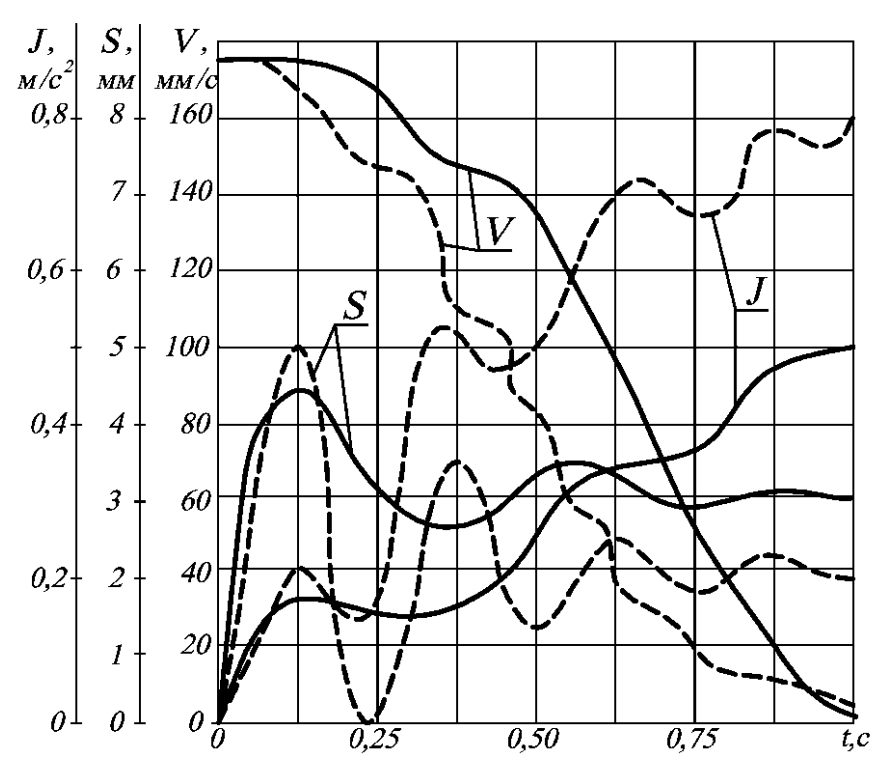

Figure 4. Curves of ram speed, displacement and acceleration while oscillating in the upper position in the case of counterbalance cylinders absence (dashed curves) and when using counterbalance cylinders in press design (solid curves) 
Numerical analysis of equation (1) for hydraulic presses with a force of $30 \mathrm{MN}, 50 \mathrm{MN}$ and $100 \mathrm{MN}$ shows that in the presence of counterbalance cylinders in the design of the press (Fig. 4) the period of oscillations increases by $75 \%$ with decreasing amplitude at least 2 times. In this case, the complete damping of oscillations occurs $0.25 \ldots 0.5 \mathrm{~s}$ earlier than in the absence of counterbalance cylinders system in the design of the press.

The mathematical model (1) of the damping oscillations of the moving parts when they are braked in the upper initial position takes into account the parameters of the oscillating system, which consists of the ram and additionally includes the mass of fluid in the working, return and counterbalance cylinders. Numerical analysis of model (1) allows to develop rational modes of fast and non-impact braking of moving parts for productive work of hydraulic presses in the conditions of automatic moves, and also to increase speed and reduce probability of occurrence of a hydraulic impact at ram reversal in the top position.

Based on the model (1), a new method of operation of hydraulic presses at idle, which can be implemented as follows [12].

1. The corresponding parameters are determined by the system of return cylinders of the hydraulic press on the basis of drawings of pipelines dilutions by means of the resulted theoretical dependences and reference sources data.

2. On the return stroke, the intake valve of the return cylinders is closed.

3. The automatic control system controls the inertial run-out of the moving parts when they are braked in the upper initial position.

4. When the ram reaches the extreme upper position during the inertial run-out, the drain valve of the return cylinders is opened so that the beginning of the forward motion coincides with the beginning of the ram lowering, while the automatic control system predicts oscillations during the inertial run-out according to model (1).

5. The approach is carried out by opening the drain valve of the return cylinders, which is opened for a time not exceeding the period of oscillation, determined by the prediction results in accordance with the given model (1).

Due to the fact that the drain valve of the return cylinders is opened the way that the beginning of the forward motion coincides with the beginning of the ram lowering, and for time not exceeding the period of oscillation determined according to the prediction results, the oscillations impact is eliminated in the upper position of the press by switching it from the reverse to the forward motion. As a result, the speed and quality of the hydraulic press control increases.

Conclusions. Studies of oscillating movements of the moving parts of hydraulic presses during their braking in the upper initial position revealed that:

- during the ram braking in the upper position of closing the intake valve of returning cylinders, run-out together with continuous oscillations and hydraulic impacts in the working systems and return cylinders are inevitable; all these significantly decrease the working performance of the press and complicates its operation in automatic mode;

- the presence of counterbalance cylinders in the design of the press, the period of oscillations increases by $75 \%$ with a decrease in amplitude by at least 2 times;

- complete atennuation of oscillations occurs by $0.25 \ldots 0.5 \mathrm{~s}$ earlier than in the absence of a system of counterbalance cylinders.

\section{References}

1. Billur E. Chapter 12: Hydraulic Presses. Sheet Metal Forming Fundamentals. ASM International, 2012. Vol. 21. P. 181-201. https://doi.org/10.31399/asm.tb.smff.t53400181

2. Zhongwei L., Yingjian D., Xinliang L. Research on simulation of giant forging hydraulic press decoupling control for synchronous control system. Research journal of applied sciences, engineering and technology. 2013. Vol. 6 (4). P. 568-574. https://doi.org/10.19026/rjaset.6.4166 
3. Z. Ouchiha, J. C. Loraud, A. Ghezal, M. Kessal and other An investigation of highly pressurized transient fluid flow in pipelines. International Journal of Pressure Vessels and Piping. Elsevier. 2012. Vol. 92. P. 106-114. https://doi.org/10.1016/j.ijpvp.2011.11.006

4. Baumann Hans D. Control valve primer: a user's guide. The Instrumentation, Systems and Automation Society (ISA), 2009. $171 \mathrm{p}$

5. Ivanov G. M., Sveshnikov V. K. Osnovnye napravlenija razvitija sovremennogo gidroprivoda. Oborudovanie i instrument dlja professionalov: metalloobrabotka. 2013. No. 4. P. 14-20.

6. Korchak E. S. Matematicheskoe modelirovanie kak osnova sozdanija sistemy jeffektivnogo tormozhenija podvizhnoj poperechiny gidravlicheskogo pressa $\mathrm{V}$ verhnem polozhenii. Vestnik Samarskogo gosudarstvennogo tehnicheskogo universiteta. Serija: Fiziko-matematicheskie nauki: sb. nauch. tr. Samara: SamGTU. 2012. No. 1 (26). P. 192-197. https://doi.org/10.14498/vsgtu917

7. Iskovich-Lotoc'kij R. D., Obertjuh R. R., Polishhuk O. V. Vikoristannja gidroimpul'snogo privodu v obladnanni pererobnih virobnictv: monografija. Vinnicja: VNTU, 2013. 116 p.

8. Korchak O. S. Nova metodyka eksperymental'nykh doslidzhen' avtomatyzovanykh system keruvannya hidravlichnymy presamy. Promyslova hidravlika i pnevmatyka. 2018. No. 2 (60). P. 48-54.

9. Korchak E. S. Decompression Dynamics of High-Pressure Hydraulic Cylinders. Russian Engineering Research. 2012. Vol. 32. No. 9-10. P. 623-626. Springer article's personal. DOI: 10.3103/ S1068798X12070143. https://doi.org/10.3103/S1068798X12070143

10. Babii A., Babii M. Taking impact of oscillation amplitude of bearing frame sections of boom sprayers into account on its resource. Scientific Journal of TNTU. Tern.: TNTU, 2019. Vol. 95. No. 3. P. 97-104. https://doi.org/10.33108/visnyk_tntu2019.03

11. Bezverhyi O., Grigoryeva L., Grigoryev S. Resonance radial oscillations of a piezoceramic cylinders and spheres taking into account electromechanical losses. Scientific Journal of TNTU. T.: THTY, 2016. T. 81. No. 1. P. 41-48.

12. Pat. 116975 Ukraini, MPK B30B15/00, B30B15/14. Sposib roboti gidravlichnih presiv na holostih hodah; zajavnik ta patentovlasnik Donbas'ka derzhavna mashinobudivna akademija (DDMA). № 201613467; zajavl. 27.12.2016; opubl. 12.06.2017, Bjul. № 11 .

\section{Список використаної літератури}

1. Billur E. Chapter 12: Hydraulic Presses. Sheet Metal Forming Fundamentals. ASM International, 2012. Vol. 21. P. 181-201. https://doi.org/10.31399/asm.tb.smff.t53400181

2. Zhongwei L., Yingiian D., Xinliang L. Research on simulation of giant forging hydraulic press decoupling control for synchronous control system. Research journal of applied sciences, engineering and technology. 2013. Vol. 6 (4). P. 568-574. https://doi.org/10.19026/rjaset.6.4166

3. Z. Ouchiha, J. C. Loraud, A. Ghezal, M. Kessal and other An investigation of highly pressurized transient fluid flow in pipelines. International Journal of Pressure Vessels and Piping. Elsevier, 2012. Vol. 92. P. 106-114. https://doi.org/10.1016/j.ijpvp.2011.11.006

4. Baumann Hans D. Control valve primer: a user's guide. The Instrumentation, Systems and Automation Society (ISA), 2009. $171 \mathrm{p}$.

5. Иванов Г. М., Свешников В. К. Основные направления развития современного гидропривода. Оборудование и инструмент для профессионалов: металлообработка. 2013. №4. С. 14-20.

6. Корчак Е. С. Математическое моделирование как основа создания системы эффективного торможения подвижной поперечины гидравлического пресса в верхнем положении. Вестник Самарского государственного технического университета. Серия: Физико-математические науки: сб. науч. тр. 2012. №1 (26). С. 192-197. https://doi.org/10.14498/vsgtu917

7. Іскович-Лотоцький Р. Д., Обертюх Р. Р., Поліщук О. В. Використання гідроімпульсного приводу в обладнанні переробних виробництв: монографія. Вінниця: ВНТУ, 2013. 116 с.

8. Корчак О. С. Нова методика експериментальних досліджень автоматизованих систем керування гідравлічними пресами. Промислова гідравліка і пневматика. 2018. № 2 (60). С. 48-54.

9. Korchak E.S. Decompression Dynamics of High-Pressure Hydraulic Cylinders. Russian Engineering Research. 2012. Vol. 32. No. 9-10. P. 623-626. Springer article's personal. https://doi.org/10.3103/S1068798X12070143

10. Babii A., Babii M. Taking impact of oscillation amplitude of bearing frame sections of boom sprayers into account on its resource. Scientific Journal of TNTU. Tern.: TNTU, 2019. Vol. 95. No. 3. P. 97-104. https://doi.org/10.33108/visnyk_tntu2019.03

11. Bezverhyi O., Grigoryeva L., Grigoryev S. Resonance radial oscillations of a piezoceramic cylinders and spheres taking into account electromechanical losses. Вісник ТНТУ. 2016. Том 81. № 1. С. 41-48.

12. Спосіб роботи гідравлічних пресів на холостих ходах: пат. 116975 України, МПК В30В15/00, В30В15/14. № 201613467; заявл. 27.12.2016; опубл. 12.06.2017, Бюл. № 11 . 


\title{
УДК 621.979:681.5
}

\section{ДОСЛІДЖЕННЯ КОЛИВАЛЬНИХ ПЕРЕМІЩЕНЬ РУХОМИХ ЧАСТИН ГІДРАВЛІЧНИХ ПРЕСІВ ПРИ ЇХ ГАЛЬМУВАННІ У ВЕРХНЬОМУ ВИХІДНОМУ ПОЛОЖЕННІ}

\author{
Олена Корчак
}

\author{
Донбаська національна академія будівництва і архітектури, \\ Краматорськ, Україна
}

\begin{abstract}
Резюме. Присвячено дослідженню коливальних переміщень рухомих частин гідравлічних пресів при їх гальмуванні у верхньому вихідному положенні та виявленню основних факторів коливальної системи, щуо впливають на інтенсивність затухання коливального руху. Дослідженнями встановлено, щчо, не зважаючи на наявність індивідуального сервопривода впускного клапана зворотних иялліндрів, вибіг рухомої поперечини вгору після його закриття, який супроводжується інтенсивними коливальними явищами, неминучий. Аналізом експериментальних діаграм виявлено, щзо існуючий механізм гальмування рухомої поперечини у верхньому вихідному положенні є неприйнятним з точки зору швидкої та безударної реалізації процесу, а також точності зупинки. Крім того, при гальмуванні рухомої поперечини у верхньому положенні закриттям впускного клапана зворотних ичліндрів неминуче має місче вибіг, який супроводжується тривалими коливаннями й гідроударами в системах робочих $i$ зворотних циліндрів, щзо суттєво знижує продуктивність преса та ускладнює його роботу в режимі автоматичних ходів. Розроблено математичну модель затухаючих коливань рухомої поперечини у верхньому положенні після закриття впускного клапана зворотних ичиліндрів, яка враховує параметри коливальної системи, щзо складається з рухомої поперечини та мас рідини в робочих і зворотних цииліндрах. Чисельним аналізом розробленої математичної моделі встановлено, щчо за наявності в конструкції преса врівноважувальних циліндрів період коливань збільшується зі зменшенням амплітуди майже вдвічі. При изьому повне затухання коливань настає раніше, ніж у випадку відсутності системи врівноважувальних ичиліндрів. Розроблено новий спосіб роботи гідравлічних пресів на холостих ходах, завдяки якому забезпечується усунення впливу коливальних явищ у верхньому положенні на перемикання преса зі зворотного на хід наближення, щзо призводить до підвищення швидкодії та якості керування гідравлічним пресом.

Ключові слова: прес гідравлічний, поперечина рухома, коливання, тиск, клапан регулювальний, вибіг, гальмування, циліндр врівноважувальний.
\end{abstract}

